\title{
EN REPLIK
}

\section{Af Tove Tybjerg}

Armin Geertz er skuffet over, at anmeldelsen af hans disputats efterlader det indtryk, at afhandlingen ikke rummer noget overordnet teoretisk synspunkt, og han tvivler p̊̊, at det har været hensigten - men det var nu hensigten. Heller ikke efter at have læst Armin Geertz' reaktion, har jeg fundet det overordnede teoretiske synspunkt. Ganske vist er det tydeligt, at Armin Geertz knytter an til den teoretiske nyorientering $\mathrm{i}$ samfundsvidenskaberne, der retter opmærksomheden mod mennesker som aktører, mod deres praksis, mod deres brug af forestillinger, mod det som Berger og Luckmann så rammende har kaldt The Social Construction of Reality, og afhandlingen demonstrerer også overbevisende, hvor frugtbart dette synspunkt er i religionshistoriske studier; Armin Geertz fastholder imidlertid ikke synspunktet konsekvent, men skifter mellem det og andre synspunkter.

Forholdet kan illustreres med et par af Armin Geertz' egne hensigtserklæringer. På s. 26 finder Armin Geertz det med et citat af Berger og Luckmann »essential to keep pushing questions about the historically available conceptualizations of reality from the abstract »What? « to the sociologically concrete "says who? ««; men i disputatsens forord understreger han, at det er analysen af det religiøse indhold, som er det væsentlige: „In contrast to sociologically oriented studies ... this study emphasizes a sustained interest in religious content and in the cognitive dimensions of prophetic apocalypse« (s. viii).

Disse - og andre - synspunkter står i afhandlingen uformidlet over for hinanden, og forholdet mellem dem afklares ikke til et overordnet teoretisk synspunkt, hvilket for så vidt ikke kan undre i betragtning af Armin Geertz' teoretiske udgangspunkt: »Ved som udgangspunkt at vælge en menneskeopfattelse, der anskuer mennesker som kulturelt kompetente, handlende individer, der ustandseligt engageres $i$ at forhandle om, opfinde, genopdage og samskabe meningsfulde fortolkninger 


\section{Review-artikel}

af deres verdener, kan vi komme til at forstå menneskelivets modsætninger, ikke så meget som modsætninger, men mere som brusen af en hermeneutisk genialitet « (dansk opsummering s. 6). Umiddelbart er det svært at se, at en menneskeopfattelse, der fører til, at modsætninger forsvinder i en brusen, kan fungere som teoretisk synspunkt.

Jeg har ikke generelt anbefalet »teori-askese«, blot manet til disciplin og omtanke i omgangen med teorier og metoder.

\section{Tove Tybjerg}

Lektor, mag.art.

Institut for Religionshistorie

Københavns Universitet 